Щербакова А. C. [1; ORCID ID: 0000-0003-0972-821X], к.е.н., доцент кафедри менеджменту Храбан А. А. ${ }^{[2]}$, судовий експерт сектору товарознавчих та гемологічних досліджень

${ }^{1}$ Національний університет водного господарства та природокористування, м. Рівне,

${ }^{2}$ Рівненський науково-дослідний експертно-криміналістичний центр МВС України, м. Рівне

\title{
ЯКІСТЬ ПРОДУКЦІЇ ЯК ЧИННИК ЗАБЕЗПЕЧЕННЯ ІНВЕСТИЦІЙНО- ІННОВАЦІЙНОГО РОЗВИТКУ ОРГАНІЗАЦІЙ СФЕРИ ТОРГІВЛІ
}

У статті обґрунтовано, що одним із найважливіших напрямків забезпечення інвестиційно-інноваційного розвитку організацій сфери торгівлі є удосконалення управління якістю продукції. Доведено, що якість - запорука успішної діяльності та процвітання будь-якої організації, а особливо організацій сфери торгівлі. Розкрито сутність поняття «якість продукції», розкрито основні рівні якості продукції. Встановлено, що висока якість продукції стає конкурентною перевагою, що забезпечує достатній рівень конкурентоспроможності суб'єктів господарювання, а відтак і стимулює їх інвестиційно-інноваційний розвиток. Визначено основні причини, що визначають необхідність забезпечення i підвищення якості продукції. Запропоновано модель стимулювання інвестиційно-інноваційного розвитку організацій сфери торгівлі, що враховує підвищення якості продукції.

Ключові слова: якість; конкурентоспроможність; інвестиційноінноваційний розвиток; продукція; організація; торгівля.

Вступ. На сучасному етапі розвитку, пріоритетним завданням більшості країн світу $\epsilon$ формування або підвищення рівня конкурентоспроможної національної економіки, як основи для забезпечення сталого розвитку держави та підвищення добробуту націй. На даний час соціально-економічний розвиток України $\epsilon$ нестабільним, його залежність від глобальної фінансово-економічної стійкості актуалізує проблему прогнозування та мінімізації негативного впливу економічних ризиків для підприємств та галузей економіки. Еволюційні перетворення економіки при переході до нових форм ринкових відносин вимагають пошуку інших, нестандартних методів управління організацією, які змогли б забезпечити істотне підвищення їі конкурентоспроможності та фінансової стійкості на ринку. Одним із найважливіших напрямків забезпечення інвестиційно-інноваційного розвитку організацій 
сфери торгівлі $€$ удосконалення управління якістю продукції. Проблема підвищення якості продукції в сучасних умовах $\epsilon$ найважливішим фактором підвищення рівня життя, економічної, соціальної, оборонної та екологічної безпеки як держави в цілому та їі регіонів, так і окремих організацій. Основна проблема, що виникла на сьогоднішній день полягає в тому, що більшість товаровиробників не приділяє належної уваги якості продукції. Останнім часом експерти неодноразово стали звертати увагу на погіршення якості більшої частини виробленої продукції. В умовах реалізації Україною торгівельної політики, відповідно до правил Світової організації торгівлі, така тенденція ставить під загрозу конкурентоспроможність та подальший розвиток вітчизняних організацій.

Аналіз останніх досліджень та публікацій. Дослідженням проблем якості та конкурентоспроможності продукції займалося досить багато вітчизняних та іноземних науковців. Зокрема дослідженнями якості як фактору підвищення ефективності діяльності організації займалися такі відомі науковці як Е. Демінг [1], Ю. Адлер [2], А. Глічев [3], Дж. Джуран [4], І. Мазур, В. Шапіро [5] та інші. Проблеми управління якістю продукції та їх влив на конкурентоспроможність підприємств розглядаються в наукових працях Т. Кузьміної, Ю. Березовського [6], В. Сторожук [7], Л. Боженко [8], О. Мишко [9], В. Панченко [10] тощо. Проте, на наш погляд, у вітчизняній практиці недостатньо досліджено вплив якості продукції (послуги) на забезпечення інвестиційно-інноваційного розвитку організацій сфери торгівлі.

Метою статті $€$ узагальнення накопиченого досвіду щодо впливу якості продукції на інвестиційно-інноваційний розвиток організацій сфери торгівлі та розробка моделі стимулювання інвестиційно-інноваційного розвитку організацій сфери торгівлі, що враховує підвищення якості продукції.

Виклад основного матеріалу. Успіх діяльності кожного підприємства-товаровиробника оцінюється рівнем ефективності виробництва, тобто, ступенем задоволення потреб суспільства за найменших витрат з обох боків. Визначальною характеристикою суспільних потреб є якість продукції, яку воно виробляє. Саме якість продукції в умовах конкуренції стає головним стимулом привернення уваги споживача [11]. Якість - запорука успішної діяльності та процвітання будь-якої організації, а особливо організацій сфери торгівлі. Оскільки, торгівля $€$ посередницькою ланкою між сферами виробництва і споживання, тому, в умовах нестабільності, вона найбільш гостро піддається ризикам втрати фінансових ресурсів, 
товарних запасів та інших матеріальних активів. Роль торгівлі на сучасному етапі розвитку України постійно зростає. Так, наприклад, у торгівлі працює практично шоста частина всього економічно активного населення України, що відповідає рівню економічно розвинутих країн.

Під якістю продукції розуміють сукупність властивостей та характеристик продукту, які надають йому здатність задовольняти встановлені або передбачувані потреби [12]. Встановлені потреби зафіксовані у правових нормах, стандартах, замовленнях, угодах, технічних умовах поставок та інших документах. Передбачувані потреби - це ті очікування, які споживач зазвичай не формулює конкретно, але відносить до стійких побажань; до них можна віднести, наприклад, відповідність продукту моді, звичкам споживачів, національним або культурним особливостям споживання тощо [13].

В ринкових умовах зусилля товаровиробників спрямовані на задоволення попиту споживачів, які в процесі вибору товару керуються його якісними характеристиками [11]. Отже, висока якість продукції стає конкурентною перевагою, що забезпечує достатній рівень конкурентоспроможності суб'єктів господарювання, а відтак і стимулює їх інноваційний розвиток. Варто відзначити, що на даному етапі розвитку суспільства, якість товарів, які споживає людина, виходить на провідне місце. Рівень життя кожної людини і суспільства загалом визначає якість товарів, особливо продуктів харчування. Споживач бажає не тільки якісно харчуватись, а і бути впевненим в тому, що продукти харчування й непродовольчі товари не завдадуть шкоди здоров'ю ні зараз, ні в майбутньому. На сьогодні у всьому світі стали суттєво жорсткішими вимоги, що висуваються споживачем до якості продукції. Ці обставини змушують інвесторів шукати такі об'єкти для інвестування, які могли б забезпечити виробництво та продаж якісної, безпечної, а також екологічно чистої продукції.

Підвищення якості продукції позитивно впливає й на результати діяльності організації. Визначальними елементами цього специфічного менеджменту, що найбільш впливає на процес виробництва і постачання на ринок конкурентоспроможної продукції, є: стандартизація і сертифікація виробів; стандартизація і сертифікація внутрішніх систем якості; державний нагляд за додержанням стандартів, норм і правил та відповідальності за їх порушення; внутрішньовиробничий технічний контроль якості. Основними причинами, що визначають необхідність забезпечення і підвищення якості продукції є: безперервне і кількісне зростання 
потреб (особистих, суспільних, виробничих), їх якісний розвиток і видозміна; зростання ролі і темпів науково-технічного прогресу в розвитку науки, техніки, виробництва, економіки; удосконалення і ускладнення конструкцій виробів, що випускаються, підвищення значущості функцій, які виконуються ними; збільшення обсягу виробництва продукції i, як наслідок, можливе зростання вартості браку; посилення вимог до інтенсифікації виробництва і підвищення його ефективності; посилення конкуренції на внутрішніх і світових ринках тощо.

Сучасні економічні процеси характеризуються розвитком як позитивних, так і негативних тенденцій. Так, на даний час, рівень якості продукції багатьох підприємств дуже низький через незадовільний стан матеріально-технічного забезпечення та використання застарілого обладнання; більшість підприємств не мають досвіду ведення конкурентної боротьби; тривала соціальноекономічна криза зумовила низьку купівельну спроможність українських споживачів. Більш того, до численних проблем минулого додалися нові, а саме: зниження інноваційної активності підприємств, неадекватність менеджменту ринковим умовам, гонитва за отриманням прибутку в короткостроковому періоді на шкоду довгостроковій стратегії виробництва конкурентоспроможної продукції. Отже, необхідним $\epsilon$ формування нових підходів до поліпшення якості продукції, що забезпечить підприємству стійкі конкурентні переваги й надасть можливість здійснювати інвестиційно-інноваційний розвиток організацій.

Міжнародний досвід свідчить, що лідерських позицій у світовій економіці, як в соціальному, так і культурному розвитку, досягають тільки ті країни, які спроможні забезпечити світову якість продукції та послуг. Це створює виробникам конкурентні переваги, а споживачам комфортні умови життя. Аналіз роботи японських підприємств показує, що випуск високоякісної продукції дозволяє отримати потрійну вигоду у вигляді більш низьких виробничих витрат, більш високих чистих доходів, більшої частки ринку. Високоякісна продукція приносить приблизно на 40\% більше прибутку на інвестований капітал, ніж продукція низької якості. На міжнародному ринку в поняття якості включається все, що сприймається споживачами, а саме: фізичні властивості; функціональні характеристики; конструктивні й ергономічні параметри; безпека користування товаром; упаковка; дозування. Оцінка якості продукції передбачає визначення абсолютного, відносного, перспективного й оптимального їі рівня, тобто кількісної характеристики міри придатності того або іншого виду продукції для 
задоволення конкретного попиту на неї порівняно з відповідними базовими показниками за фіксованих умов споживання (рис. 1).

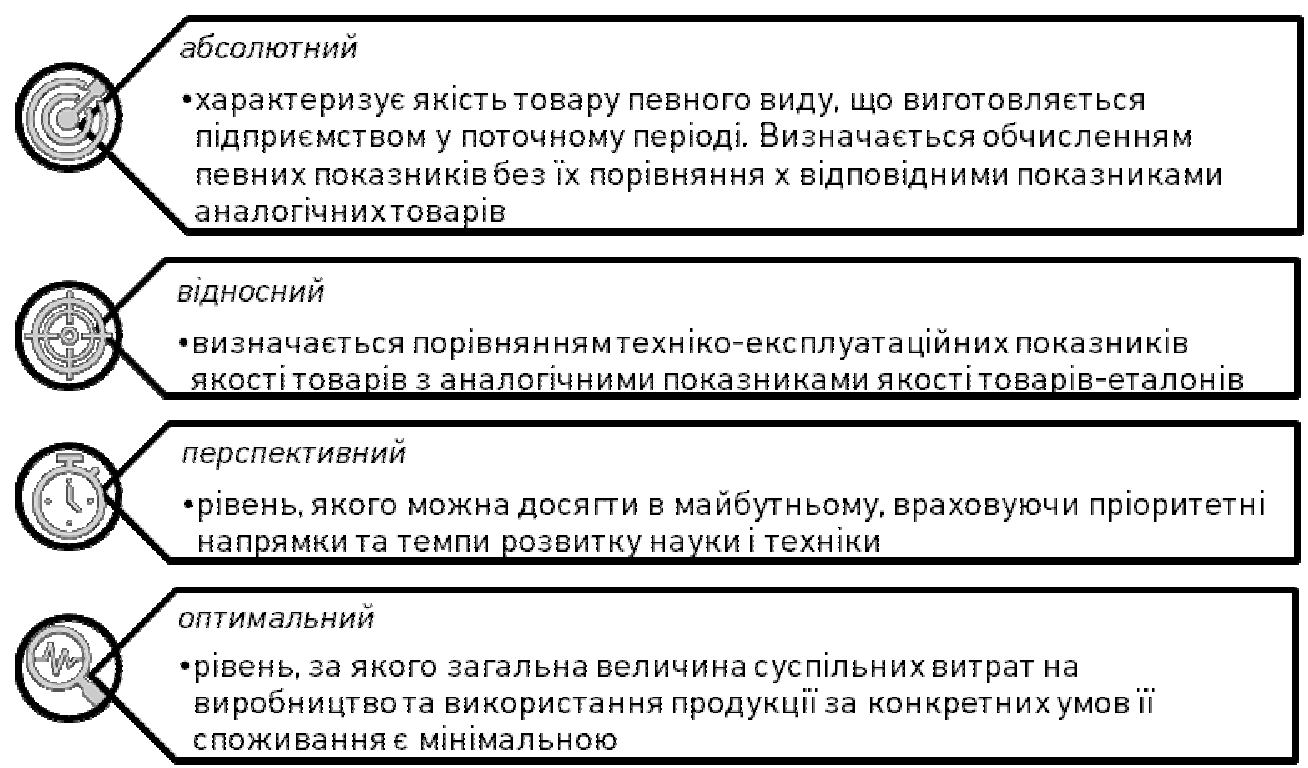

Рис. 1. Рівні якості продукції

Одним з ефективних засобів забезпечення конкурентоспроможності та стійкості вітчизняних підприємств $\epsilon$ гнучкість його виробничих систем, здатність адаптуватись до змін умов функціонування з меншими витратами і без втрат. Пошук своїх споживачів, розроблення нових видів продукції самі не можуть зберегти конкурентні переваги та стійкість підприємства, якщо якість виготовлення продукції не відповідає світовим стандартам.

Соціально-економічне значення підвищення якості й конкурентоспроможності продукції полягає в тому, що заходи спрямування сприяють формуванню ефективнішої системи господарювання за умов ринкових відносин. Соціально-економічна ефективність підвищення конкурентоспроможності продукції, що виготовляють підприємствами полягає передусім у тому, що високоякісна та конкурентоспроможна продукція завжди повніше й краще задовольняє суспільно-соціальні потреби в ній; підвищення якості продукції є специфічною формулою виявлення закону економії робочого часу; конкурентоспроможна продукція забезпечує постійну фінансову стійкість підприємства та сприяє покращанню кінцевих фінансових результатів діяльності підприємства [13].

Більшість підприємств розглядають якість як високоефективний засіб обійти конкурентів за допомогою постійної пропозиції на ринку товарів та послуг, що за допомогою вищих якісних характеристик краще задовольнять потреби споживачів ніж аналогічна продукція конкурентів. На нашу думку, провідну роль у 
забезпеченні населення високоякісною продукцією відіграють організації сфери послуг як посередники між виробниками та населенням. Реалізація лише високоякісної продукції спонукатиме підприємства-виробників до більш серйозного контролю за якістю сировини, відповідністю продукції міжнародним стандартам. Основною задачею на даний час повинно стати стимулювання запровадження високоякісної, екологічно безпечної та конкурентоспроможної продукції 3 використанням новітніх технологій для підвищення інвестиційно-інноваційного розвитку організацій сфери послуг (рис. 2).

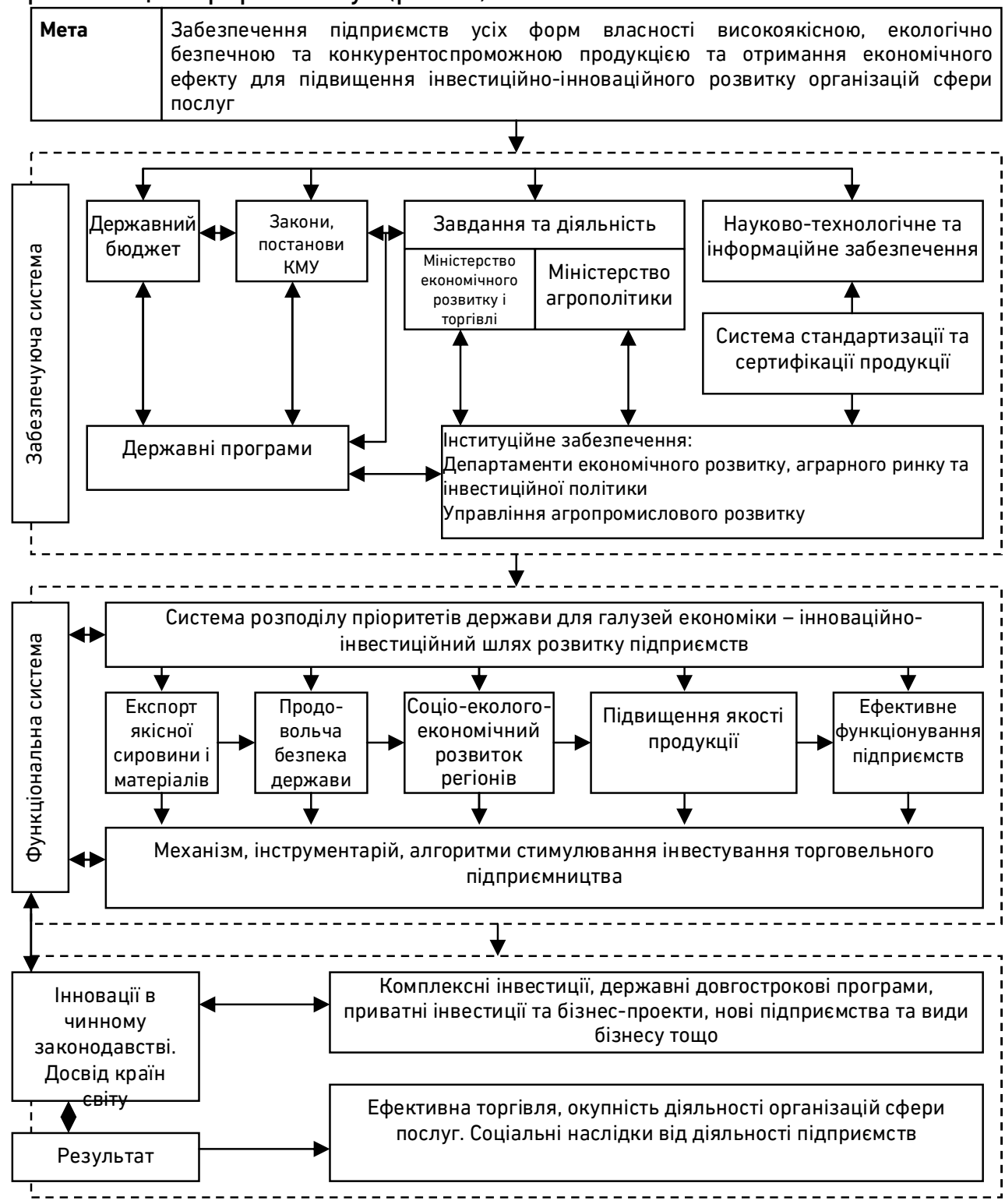

Рис. 2. Модель стимулювання інвестиційно-інноваційного розвитку організацій сфери послуг (розроблено автором) 
Інвестиційно-інноваційний розвиток організацій сфери послуг передбачає необхідність стимулювання розвитку екологічно чистого, органічного сільськогосподарського виробництва в Україні, що включає розробку і затвердження законодавчої і відповідної нормативної бази, яка б регулювала галузь, а також запровадження зрозумілих і прозорих фінансових механізмів стимулювання розвитку «органіки». Для підвищення рівня конкурентоспроможності вітчизняної продукції на європейському ринку необхідно, в першу чергу, гармонізувати вітчизняні стандарти на екологічно чисту продукцію згідно зі стандартами ЄС. Крім того, на нашу думку, слід розробити та реалізувати державну програму просування українських якісних та безпечних товарів, сільськогосподарської продукції та продовольства на зовнішні ринки, включаючи країнучасниць СОТ та ЄС. Головним елементом промоційних програм повинно бути підкреслення конкурентних переваг української продукції, насамперед іï якості, гігієни, безпечності, харчових цінностей. Для того, щоб товар був конкурентоспроможним, необхідно оптимізувати всі ланки виробничого циклу товару так, щоб ціна продукції відповідала ї̈ якості, а також рівню сервісу, та щоб товар був доступним для споживача.

Основними напрямками підвищення якості та, як наслідок, конкурентоспроможності продукції, на нашу думку, можуть бути: використання досягнень науки й техніки в процесі проектування виробів; впровадження новітніх технологій виробництва та суворе дотримання технологічної дисципліни; удосконалення стандартів і технічних умов, що застосовуються, сертифікація продукції; удосконалення методів контролю та самоконтролю на всіх стадіях виготовлення продукції; забезпечення переробних підприємств високоякісною сільськогосподарською сировиною; розширення прямих господарських зв'язків між виробниками та споживачами; узагальнення та використання передового вітчизняного та зарубіжного досвіду щодо підвищення якості та конкурентоспроможності продукції; запровадження систем управління якістю та безпечністю харчової продукції, побудованих на принципах НАССР; застосування узгодженої системи прогнозування та планування необхідного рівня якості виробів; використання належної мотивації праці всіх категорій персоналу; всебічна активізація людського чинника та проведення кадрової політики, яка адаптована до ринкових умов господарювання; створення програм фінансування проектів по підвищенню якості продукції тощо.

Висновки та пропозиції. Для економіки в цілому підвищення 
якості продукції дасть можливість посилити позиції вітчизняних виробників продовольства як на внутрішньому, так і на світовому ринках, розширити можливості виходу на зарубіжні ринки, яким притаманна висока платоспроможність, розвинути торгову та економічну співпрацю, покращити інвестиційний клімат, що принесе додаткові надходження засобів як на рівні окремої організації, так і на рівні країни, сприятиме її оздоровленню, зміцненню і розвитку. Запровадження моделі якісного, безпечного та екологічно чистого виробництва продукції дозволить підвищити конкурентоспроможність організацій сфери торгівлі шляхом отримання економічного та екологічного ефекту, підвищити їх інвестиційну привабливість, прибутковість, ринкову вартість, сприятиме створенню передумов реалізації стратегії індустріального розвитку національної економіки на інноваційних принципах, іï модернізації та оновлення.

1. Deming W. Edwards. The New Economics: For Industry, Government, Education. 3d ed. Cambridge, Massachusetts : MIT Press, 2018. 240 р. 2. Адлер Ю. П., Шпер В. Л. Будущее качества и систем менеджмента качества. Актуальные проблемы экономики и права. 2017. № 2. Т. ІІ. С. 5-18. 3. Гличев А. В. Качество, эффективность, нравственность. Москва : 000 «Премиум Инжиниринг», 2009. 358 с. 4. Joseph М. Juran, Joseph A. De Feo. Juran's Quality Handbook: The Complete Guide to Performance Excellence. $7^{\text {th }}$ edition. The McGraw-Hill Companies, Inc., 2017. $1113 \mathrm{p}$. 5. Мазур И. Н., Шапиро В. Д. Управление качеством : учеб. пособ. Москва : Изд-во «Омега-Л», 2010. 400 с. 6. Кузьміна Т. О., Березовський Ю. В., Стрелюк Л. 0. Удосконалення системи управління якістю послуг підприємств. Товарознавчий вісник. 2019. Вип. 12. С. 316-326. 7. Сторожук В. П. Управління підприємствами та організаціями споживчої кооперації на засадах функціонального підходу : монографія. Полтава : РВВ ПУСКУ, 2008. 155 с. 8. Боженко Л., Гурта О. Управління якістю, основи стандартизації та сертифікації продукції : навч. посіб. Львів : Афіша, 2012. 157 с. 9. Мишко 0. Управління якістю - запорука підвищення конкурентоспроможності продукції. Економіка, фінанси, право. 2014. № 3. С. 41-44. 10. Панченко В. Теоретичні аспекти управління якістю торговельного обслуговування на засадах системного підходу. Наукові праці Кіровогр. нац. техн. ун-ту. Екон. науки. 2009. Вип. 15. С. 399-407. 11. Биба В. В., Теницька Н. Б. Якість продукції як чинник конкурентоспроможності підприємства. Економіка $i$ суспільство. 2017. Вип. 12. С. 171-176. 12. Мороз О. В., Ткачук Л. М. Організаційноекономічні фактори управління якістю на підприємствах : монографія. Вінниця : УНІВЕРСУМ-Вінниця, 2005. 137 с. 13. ЦилюрикГ.І. Якість товару - ключовий важіль забезпечення його конкурентоспроможності. Облік $i$ фінанси АПК: бухгалтерський портал. URL: http://magazine.faaf.org.ua/yakist-tovaru-klyuchoviyvazhil-zabezpechennya-yogo-konkurentospromozhnosti.html (дата звернення: 15.12.2020). 


\section{REFERENCES:}

1. Deming W. Edwards. The New Economics: For Industry, Government, Education. 3d ed. Cambridge, Massachusetts : MIT Press, 2018. 240 p. 2. Adler Yu. P., Shper V. L. Buduschee kachestva i sistem menedjmenta kachestva. Aktualnyie problemyi ekonomiki i prava. 2017. № 2. T. II. S. 5-18. 3. Glichev A. V. Kachestvo, effektivnost, nravstvennost. Moskva : 000 «Premium Injiniring», 2009. 358 s. 4. Joseph M. Juran, Joseph A. De Feo. Jurans Quality Handbook: The Complete Guide to Performance Excellence. 7th edition. The McGraw-Hill Companies, Inc., 2017. 1113 p. 5. Mazur Y. N., Shapyro V. D. Upravlenye kachestvom : ucheb. posob. Moskva : Yzd-vo «Omeha-L», 2010. 400 s. 6. Kuzmina T. O., Berezovskyi Yu. V., Streliuk L. O. Udoskonalennia systemy upravlinnia yakistiu posluh pidpryiemstv. Tovaroznavchyi visnyk. 2019. Vyp. 12. S. 316-326. 7. Storozhuk V. P. Upravlinnia pidpryiemstvamy ta orhanizatsiiamy spozhyvchoi kooperatsii na zasadakh funktsionalnoho pidkhodu : monohrafiia. Poltava : RVV PUSKU, 2008. 155 s. 8. Bozhenko L., Hurta O. Upravlinnia yakistiu, osnovy standartyzatsii ta sertyfikatsii produktsii : navch. posib. Lviv : Afisha, 2012. 157 s. 9. Myshko 0. Upravlinnia yakistiu - zaporuka pidvyshchennia konkurentospromozhnosti produktsii. Ekonomika, finansy, pravo. 2014. № 3. S. 41-44. 10. Panchenko V. Teoretychni aspekty upravlinnia yakistiu torhovelnoho obsluhovuvannia na zasadakh systemnoho pidkhodu. Naukovi pratsi Kirovohr. nats. tekhn. un-tu. Ekon. nauky. 2009. Vyp. 15. S. 399-407. 11. Byba V. V., Tenytska N. B. Yakist produktsii yak chynnyk konkurentospromozhnosti pidpryiemstva. Ekonomika $i$ suspilstvo. 2017. Vyp. 12. S. 171-176. 12. Moroz 0. V., Tkachuk L. M. Orhanizatsiinoekonomichni faktory upravlinnia yakistiu na pidpryiemstvakh : monohrafiia. Vinnytsia : UNIVERSUM-Vinnytsia, 2005. 137 s. 13. Tsyliuryk H. I. Yakist tovaru - kliuchovyi vazhil zabezpechennia yoho konkurentospromozhnosti. Oblik i finansy APK: bukhhalterskyi portal. URL: http://magazine.faaf.org.ua/yakist-tovaru-klyuchoviy-vazhilzabezpechennya-yogo-konkurentospromozhnosti.html (data zvernennia: 15.12.2020).

Shcherbakova A. S. ${ }^{[1 ; 0 R C I D ~ I D: ~ 0000-0003-0972-821 X] ~}$ Candidate of Economics (Ph.D.), Associate Professor of Management department

Khraban A. A. ${ }^{[2]}$, Forensic Expert of the Sector of Commodity and Gemological Research

${ }^{1}$ National University of Water and Environmental Engineering, Rivne

${ }^{2}$ Rivne Research Forensic Center of the Ministry of Internal Affairs of Ukraine, Rivne

\section{PRODUCT QUALITY AS A FACTOR OF ENSURING THE INVESTMENT AND INNOVATION DEVELOPMENT OF TRADE ORGANIZATIONS}

At the present stage of development, the priority of most countries is to form or increase the level of competitive national economy as a basis for sustainable development of the state and increase the welfare of nations. In the article has been substantiated that one of the most important areas of investment and innovation development of trade organizations is to improve product quality management. It is proved that quality is the key to successful activity and prosperity of any organization, especially trade organizations. The essence of the «product quality» concept of has been revealed. It is 
substantiated that the assessment of product quality involves determining the absolute, relative, prospective and optimal level, i.e. the quantitative characteristics of the degree of suitability of a product to satisfy a specific demand for it compared to the relevant basic indicators under fixed consumption conditions. It has been established that high quality products become a competitive advantage, that provides a sufficient level of competitiveness of economic entities, and thus stimulates its investment and innovation development. In the article have been grounded that main reasons that determine the need to ensure and improve a product quality are: continuous and quantitative growth of needs (personal, social, industrial), its qualitative development and modification; growth of the role and pace of scientific and technological progress in the development of science, technology, production, economy; improving and complicating the design of manufactured products, increasing the importance of the functions performed by them; increasing the amount of production and, as a consequence, a possible increasing the cost of defects; strengthening the requirements for intensification of production and increasing its efficiency increasing the competition in domestic and global markets, etc. A model of stimulating the investment and innovation development of trade organizations has been proposed, that takes into account the improvement of product quality.

Keywords: quality; competitiveness; investment and innovation development; product; organization; trade.

Щербакова A. C. [1; ORCID ID: 0000-0003-0972-821X],
К.э.Н., доцент кафедры менеджмента,
Храбан А. А. ${ }^{[2]}$,
судебный эксперт сектора товароведных и геммологических
исследований

${ }^{1}$ Национальный университет водного хозяйства и природопользования, г. Ровно ${ }^{2}$ Ровенский научно-исследовательский экспертно-криминалистический центр МВД Украины, г. Ровно

\section{КАЧЕСТВО ПРОДУКЦИИ КАК ФАКТОР ОБЕСПЕЧЕНИЯ ИНВЕСТИЦИОННО-ИННОВАЦИОННОГО РАЗВИТИЯ ОРГАНИЗАЦИЙ СФЕРЫ ТОРГОВЛИ}

В статье обосновано, что одним из важнейших направлений обеспечения инвестиционно-инновационного развития организаций сферы торговли является совершенствование управления качеством продукции. Доказано, что качество - залог успешной деятельности и процветания любой организации, особенно организаций сферы торговли. 
Раскрыта сущность понятия «качество продукции», раскрыты основные уровни качества продукции. Установлено, что высокое качество продукции становится конкурентным преимуществом, которое обеспечивает достаточный уровень конкурентоспособности субъектов хозяйствования, а следовательно, и стимулирует их инвестиционноинновационное развитие. Определены основные причины, определяющие необходимость обеспечения и повышения качества продукции. Предложена модель стимулирования инвестиционноинновационного развития организаций сферы торговли, учитывающий повышение качества продукции.

Ключевые слова: качество; конкурентоспособность; инвестиционноинновационное развитие; продукция; организация; торговля.

Стаття надійшла до редакції 16.12.2020 p. 